Article

\title{
Social Entrepreneurship on Its Way to Significance: The Case of Germany
}

\author{
Karina Cagarman ${ }^{1, *}$, Jan Kratzer ${ }^{1}$, Laura Helen von Arnim ${ }^{1}\left(\mathbb{D}\right.$, Kristina Fajga $^{2}$ \\ and Michaela Jacqueline Gieseke ${ }^{2}$ \\ 1 Department of Technology and Management, Technische Universität Berlin, Straße des 17. Juni 135, H76, \\ 10623 Berlin, Germany; jan.kratzer@tu-berlin.de (J.K.); laura.middermann@tu-berlin.de (L.H.v.A.) \\ 2 Centre for Entrepreneurship, Technische Universität Berlin, Hardenbergstr. 38, 10623 Berlin, Germany; \\ kristina.fajga@tu-berlin.de (K.F.); gieseke@tu-berlin.de (M.J.G.) \\ * Correspondence: karina.cagarman@tu-berlin.de
}

Received: 14 September 2020; Accepted: 22 October 2020; Published: 28 October 2020

\begin{abstract}
The environmental context plays a very important role in the success of entrepreneurial behaviour. Governments used this opportunity by introducing specific programmes, but do social entrepreneurs have a comparable chance of getting governmental support as commercial entrepreneurs do in these programmes? We analyze the EXIST Start-up Grant in terms of likelihood for entrepreneurs following economic and social sustainable development goals (SDGs). Our results indicate that there is a decreased probability to get the EXIST Start-up Grant when following social SDGs. We argue that it is about time to introduce specific programmes for social innovation and/or reassess existing programmes in terms of their openness to social entrepreneurs.
\end{abstract}

Keywords: social entrepreneurship; government support; sustainable development goals; funding

\section{Introduction}

In contrast to commercial entrepreneurship, social entrepreneurs pursue the goal of creating societal or social added value [1-3] or finding solutions to social challenges [4,5]. Mair and Marti argue that social entrepreneurship is accompanied by economic outcomes alongside its social mission by defining social entrepreneurship as "a process involving the innovative use and combination of resources to pursue opportunities to catalyze social change and/or address social needs" [4] (p.37). The element of social entrepreneurs acting as a catalyst for social change is also pointed out by other researchers $[6,7]$. Therefore, social entrepreneurship is one of the driving forces for achieving the Sustainable Development Goals (SDGs) [8] that represent 17 goals that were set by the United Nations in order to achieve a more sustainable and better future for the world. However, social entrepreneurs have a two-sided model since they follow their business activities besides pursuing their social mission [9], which means that they have to satisfy more stakeholders than commercial entrepreneurs. According to the Deutscher Social Entreprenership Monitor [10] 96.7\% of social start-ups declare that the social impact is at least equivalent with financial return but in most cases is even more important.

After the conceptual understanding of the phenomena, and the topic of social impact and value creation, resources supporting and financing social entrepreneurship and decision making by social investors is the third most addressed research area within social entrepreneurship [11]. Consequently, it seems to be one of the most sensitive matters within this research field after understanding the concept and its impact on society. The structured literature review conducted by showed that social entrepreneurs face a variety of challenges [12]. The greatest four are to gain access to funds, a lack of a legal framework, scarcity of support structures, and absence of special training 
programmes. Social entrepreneurs have to prove that they are foremost creating social value and moreover act upon a profitable business model.

Research shows that the introduction of specific programmes targeted at self-employment affect entrepreneurship activities [13]. Therefore, the number of organizations can be boosted by providing additional funding to a specific sector as shown in the case of voluntary social service organizations in Toronto by [14]. Consequently, "the institutional factors impacting entrepreneurial efforts include the direct action of governments in constructing and maintaining an environment supportive of entrepreneurship as well as societal norms toward entrepreneurship," [15]. An active government is able to enhance social entrepreneurship by supporting it $[1,16,17]$. Although the German government confirms the importance of social entrepreneurs for the economy and society $[18,19]$, governmental support for this type of entrepreneurship still needs to be improved. This is due to the ambiguous model that makes it very difficult to create governmental programmes that support social entrepreneurs. The usual programmes offered in Germany are mainly focused on innovation and economical sustainability. The EXIST start-up grant is the major source of governmental pre-seed support of academic start-up in Germany. The criteria of EXIST start-up grants are based on the contribution of start-ups to widen technology-based and innovative knowledge, and to be economical feasible. The United States, United Kingdom, and South Korea are recognized as providing a mature policy framework for social entrepreneurship [20]. Amongst a huge set of supporting policies, these governments support social entrepreneurship by putting it on their agenda and creating a vibrant ecosystem for social entrepreneurs.

The number of academic articles on the impact of context on social entrepreneurship is growing; however, research on governmental support has not been satisfactorily discussed. This is especially true for the comparison of governmental support for commercial and social entrepreneurs. Our research follows recent calls for more consideration of the influence of context on social entrepreneurship by analyzing the contextual settings in terms of country specific features such as institutional and regulatory environments [12]. We apply the framework of institutional theory to compare the support of commercial and social entrepreneurship in Germany. Plenty of studies compare countries [21,22], but we argue that there are also differences when comparing two different types of entrepreneurship within the same regional context.

The paper is structured as follows: first, the theoretical framework is presented and the situation in Germany is described. The hypotheses are derived based upon theory and insights about the current state in Germany. Second, we discuss the data set, present the measures, the research design, and conduct the statistical analysis. Finally, we discuss the results that indicate a lower chance of getting an EXIST Start-up Grant for social entrepreneurs and a higher chance for commercial entrepreneurs, provide suggestions for future research as well as practical implications, and conclude with the limitations of this study.

\section{Literature Review}

\subsection{Entrepreneurship in Germany}

There are several benefits economies draw from entrepreneurship [23], such as creation of employment, contribution to productivity growth and produce, and commercialization of high-quality innovations. The benefits make it very attractive for governments to invest in entrepreneurship. However, there are national differences in the importance and support of entrepreneurship. In contrast to entrepreneurial societies such as the United States or Australia, Germany had to place entrepreneurship on its political agenda. "Start-ups became a hot topic in politics partly out of conviction (ambitions to create an "entrepreneurial society") and partly out of necessity (the realization that large companies in the past have made job cuts, while start-ups really can only grow)," [24] (p.205).

Starting in 1950, the number of entrepreneurs in Germany declined steadily from 15\% [25]. The decrease was heavily associated with the declining numbers of farmers, especially in the 1950s 
and 1960s. In 1997, the president of Germany, Roman Herzog, addressed the stagnating economy and the loss of its dynamic in a speech by pointing out that a climate has to be created where people see a career perspective in creating businesses [26]. From this point on it was on the agenda of the politicians, even if it was not in the primary focus. In the following years, a variety of initiatives and programmes were created to improve the entrepreneurial framework conditions. Special programmes were introduced to encourage female founders, high school students, as well as initiatives for founders with a migration background. These interventions by the German government played an essential role in the development of an entrepreneurial culture within the country [24].

According to the Global Entrepreneurship Monitor (GEM) report 2019, Germany reached the highest level of Total early-stage Entrepreneurial Activity (TEA) in 2019, namely 7.6\% [27]. The report from the Kreditanstalt für Wiederaufbau (KfW) estimates 605,000 newly founded businesses in 2019, which account for $1.17 \%$ [28]. When adding employed people (6.4\%) with plans to set up a business in the near future as reported by [28], the numbers round up with the numbers on TEA from GEM, since the TEA indicator not only includes the people who have started their entrepreneurial activity but also people who are about to start an entrepreneurial activity. However, in the comparison with other "high-income countries" on their TEA scale Germany is amongst the last, ranked 28th out of 33 [27].

In terms of environmental conditions, the National Entrepreneurship Context Index (NECI) introduced by GEM can be used to compare countries worldwide. NECI is an assessment method that includes twelve indicators to evaluate external context factors that have an influence on entrepreneurship [29]. According to the NECI, Germany is ranked 15th in the GEM report from 2018/2019 and 16th in the GEM report 2019/2020 [27,29,30]. Besides the weaknesses on the basic school entrepreneurial education and training, experts asses the labour market as rather unfavorable for start-up activities. Entrepreneurial activities are strongly correlated with the number of job vacancies [28]. Following this, a high number of job vacancies leads to less entrepreneurial activity. Furthermore, experts do not see a prioritization of entrepreneurship and engagement in politics as well as benefits from the regulation and taxation side [31].

\subsection{Social Entrepreneurship in Germany}

The development of social entrepreneurship and the research into social entrepreneurship is very multifaceted. A very recent study by discusses the country-specific and cultural differences in the development and perception of social entrepreneurship [32]. These differences have shaped research attempts up to now and partly bias results. In our study, therefore, we decided to focus on Germany, which has its own history and perception of social entrepreneurship, and in addition very specific governmental programs. Although the concept of social entrepreneurship was always around it was introduced into the academic literature as such in 1991 [33]. In the beginning it did not get a lot of attention. After Muhammad Yunnus and Grameen Bank were awarded the Nobel Prize in 2006, social entrepreneurship as a research field started to get more attention and grew exponentially. The Sustainable Development Goals that were adopted by all United Nations Member States in 2015 contributed to the growth of interest in this field. Indicators such as the exponential growth of publications, emergence of new specific journals, new conferences, dedicated professorships, and others show that social entrepreneurship started to establish itself as a distinct research field [11]. Consequently, the concept of social entrepreneurship became an essential part of entrepreneurship and, besides corporate entrepreneurship, one of the most studied typologies of entrepreneurship in the last few decades.

From a historical point of view, social entrepreneurship gained great importance after World War II when existing government support was not able to offer solutions to the society [34]. Consequently, social entrepreneurs were the initiators who took over previous government tasks [35]. Germany is a country close to the Bismarckian model [36], where non-profit organizations that are predominantly publicly funded and regulated play a significant role in the delivery of social services [37]. However, Germany has not taken advantage of the resources and potential that social entrepreneurs can bring to society [38]. 
Germany is ranked 125th out of 190 countries on its difficulty to start a business [39]. For non-profit organizations there is an additional hurdle since they have to prove their charitable cause to get some tax incentives. Apart from this the strong German welfare state and its interdependencies with welfare organizations, mostly connected to the church [40], as well as the lack of start-up culture in Germany, create potential barriers for social entrepreneurship. As social entrepreneurs focus firstly on their social mission the profitability is usually lower when comparing it to commercial entrepreneurship. Consequently, this limits the accessibility of financing opportunities from private investors. There are several public funding programmes available; however, there is no programme with a specific focus on social innovation/entrepreneurship. This discrepancy is also recognized by the European Union and its Commission Expert Group on Social Entrepreneurship [41] who have published a call for action where concrete policy recommendations are provided and two out of four topics are improving access to funding as well as improving the legal environment.

In the special issue from GEM on social entrepreneurship in 2015 Germany is ranked 21st for its prevalence of nascent social entrepreneurial activity in the cluster of innovation-driven economies $(0.8 \%)$ and 19 th on its prevalence of individuals in operational post-start-up social entrepreneurial activity $(1.5 \%)$. In contrast to that, $41.9 \%$ of start-ups surveyed for the Deutscher Startup Monitor agrees or strongly agree with the statement that their products/services can be assigned to social entrepreneurship [42]. In terms of the environmental conditions the Thomson Reuters Foundation evaluated a set of countries by assessing the environment for social entrepreneurs [43]. In their survey of "the best country to be a social entrepreneur" Germany fell from rank 12 in 2016 to rank 21 in 2019. Nevertheless, Berlin has confirmed its position as the world's hotspot for social entrepreneurship. This can be attributed to its historical and cultural background as well as its rich infrastructure including co-working spaces, incubators, and accelerators.

\section{Theoretical Background and Hypothesis}

\subsection{Institutional Theory}

Entrepreneurship literature shows clearly that the context, including the legal environment, culture, history of an industry and provided economic incentives, can impact an industry and consequently entrepreneurial success [44]. Institutional theory proved to be a valid theoretical lens for entrepreneurship research that is described as "concerned with regulatory, social, and cultural influences that promote survival and legitimacy of an organization" [15]. This conceptual framework is reliable and suitable to analyze the impact of environmental factors on entrepreneurship [45].

Institutions are restrictions developed by human beings to structure political, economic, and social interactions with the goal to establish order and decrease uncertainty [46]. North recognizes two forms of institutions namely formal and informal ones. Formal institutions are seen as the reasons of economic progress of Western developed economies, whereas developed countries are lagging behind despite their powerful informal institutions [46]. Scott summarized the three categories of the institutional theory, namely the regulative, normative, and cognitive pillars [47]. The regulative pillar refers to the formal institutions comprises of governmental regulations and industry standards and agreements. Whereas the normative pillar consists of values and norms that people confirm to. Finally, the cognitive pillar covers rules and meanings that guide beliefs and behavior [48]. The normative and cognitive pillars represent informal institutions.

The degree of entrepreneurship that occurs within a society is directly linked to regulations and policies regulating the allocation of rewards within this society [44]. Kostova highlights the importance of a more pro-active role of the government by investing in the three pillars (regulatory, normative, and cognitive) to facilitate certain behaviours [49]. Since newly founded enterprises need to seek legitimacy [15], and the term legitimacy, described in an easy way, is the right to exist and undertake an activity in a particular way [50], the government can support this process by introducing specific programmes. Therefore, the government plays a vital role in the formation of 
new forms of organizations with increased legitimacy, by stimulating demand or direct subsidies [51]. Institutional theory helps to understand how entrepreneurs must seek for the legitimacy of the ventures they newly created [52].

This article is based upon institutional theory, whereby the focus lies on formal institutions and its regulatory dimension that is represented by public policies and provided support to entrepreneurs in the first phases of their entrepreneurial activity.

\subsection{Economical SDGs and the Likelihood of Institutional Support in Germany}

The strong entrepreneurial framework conditions in Germany are protection of intellectual property, appreciation of new products/services from a consumer perspective, public funding programmes, and physical infrastructure [31]. According to the GEM report, Germany's public funding programmes are counted as one of the comparative strengths as an entrepreneurial framework condition globally $[27,29]$. In terms of public funding programmes, Germany was ranked amongst the top six countries, wherefrom it was ranked first seven times in the twenty years of the GEM data collection. This is due to a range of funding instruments that the German government offers for start-ups as well as companies in their growth phase [53]. Institutional support programmes include different loan and grant programmes such as ERP Start-up Loan, ERP Capital, ERP Innovation financing, High-tech Start-up Fund, INVEST, EXIST Start-up Grant, Micro-Mezzanine Fund, and others. Micro-Mezzanine Fund is the only programme that mentions social entrepreneurs as eligible applicants. However, EXIST is the only programme providing funding for the idea development phase and therefore encouraging entrepreneurs to work on their business ideas and writing a business plan.

The EXIST Start-up Grant supports students, scientists and graduates from universities or research institutions and provides funding for the individual team members (up to three people) to give them time to work on their business idea and write a business plan. In order to be eligible for the grant, the idea should be innovative in nature and can be a technology or a knowledge-based project. From the start of the programme in 2007, a total of 3982 founders applied for the EXIST Start-up Grant and 2214 were successful [54]. According to a report from 2013, out of 752 supported start-up projects 585 were registered as a business and $84 \%$ of the registered businesses were still active in 2013 at the time of the data collection (5 years of running EXIST).

In an additional survey from the KfW-Gründungsmonitor (Metzger, 2020) founders themselves were asked to rank the environmental conditions as opposed to the NECI results based upon expert interviews conducted for the GEM $[27,28]$. According to this ranking free market access, founder image, quality of the infrastructure, protection of intellectual property and advisory services are ranked at the top whereas free market access is ranked as "good" and the other conditions as "satisfactory". Taxation, credit availability, political commitment, and the education system in terms of an entrepreneurial education are here ranked as sufficient comparable to the results of the expert interview from GEM.

Although experts rate government entrepreneurship programmes as quite high, entrepreneurs rank the access to public funding as rather satisfactory. However, only $6 \%$ see access to public funding as a perception of obstacles and only $13 \%$ see it as an obstacle from the people who abandoned their entrepreneurial plans [28]. Even though entrepreneurs rank public funding as satisfactory in general it can be said that the conditions are quite good, since Germany has many programmes that can be used by entrepreneurs. Apart from that, the environmental condition in terms of public funding is ranked very high in a worldwide comparison. EXIST is addressed to entrepreneurs with an innovative technology or knowledge-based idea and economic feasibility is one of the selection criteria. Although that opens for all innovative and knowledge-based start-ups, the economic feasibility might outperform other criteria and therefore we propose:

Hypothesis 1 (H1). Addressing economic SDGs increases the probability of getting the EXIST Start-up Grant. 


\subsection{Social SDGs and the Likelihood of Institutional Support in Germany}

Research confirms that institutional support for social entrepreneurship creates more engagement in social entrepreneurship activities [55]. Consequently, governmental support should encourage social entrepreneurs to apply for governmental support programmes and provide equal chances when allocating these funds. However, according to a survey by Deutscher Social Entrepreneurship Monitor (DSEM) social entrepreneurs in Germany in most cases (73.1\%) use their own money, make use of financial support from family and friends $(30.7 \%)$ and in some cases $(23.1 \%)$ have the possibility of using public funds. The support by the German government is evaluated as sufficient to deficient. Even in Berlin, which is labelled as the hotspot for social entrepreneurs, the governmental support is rated 4.3 (on a scale from $1=$ very good to $6=$ insufficient). One of the barriers for social entrepreneurs is the difficulty of understanding how public funds are allocated $(60.8 \%)$.

In total, $50.5 \%$ of the sample did not take advantage of any support programmes. Some social entrepreneurs made use of the Social Impact Lab (22.2\%), followed by Ashoka (15.1\%) and startsocial $(12.3 \%)$. EXIST was only used by $2.4 \%$ of the surveyed social entrepreneurs. In total, $32.7 \%$ of the surveyed social entrepreneurs who got public funding indicated that it is rather difficult or very difficult to get it (Question about the difficulty is based on a small sample of 49 entrepreneurs). In terms of EXIST, the German government states that $12 \%$ of EXIST funding is allocated to social entrepreneurs [19]. This is not surprising since the competition with commercial entrepreneurs makes it difficult for social entrepreneurs. Commercial entrepreneurs stand a better chance due to their economical sustainability and higher chances of scalability. As mentioned before, the German government admits that the framework conditions for social entrepreneurs are not ideal and that "the consulting and supportive services are being reviewed, further developed and more visibly communicated with a view to their possible use by social entrepreneurs," [19]. Thus, it might be assumed that following social SDGs is rather a hindrance to get access to public funding, because in the perception of many it negatively correlates with economic feasibility. This perception might also influence decisions around granting EXIST scholarships to start-ups. Consequently, we propose:

Hypothesis 2 (H2). Addressing social SDGs decreases the probability of getting the EXIST Start-up Grant.

\section{Methodology}

\subsection{Data}

For this study, we use data that was collected in a harmonized start-up survey. This survey is a structured and systematic analysis of start-up activities with a connection to public universities in the Berlin-Brandenburg metropolitan region (Germany). For the third time, these start-up activities have been thoroughly and uniformly surveyed as part of a cross-university initiative. A standardized questionnaire was created to obtain and analyze relevant key data from the founders and companies. The online survey was set up in English and German. The target group were self-employed individuals/start-up entrepreneurs with a connection to the ten participating universities-be it as alumni, student, or scientific staff. The period of survey was 1 February $2020-15$ March 2020. The data were obtained prior to the outbreak of the coronavirus pandemic in Germany and refer mostly to 2019. The online survey reached out to a total of 5120 companies and self-employed individuals, of whom 750 took part. This corresponds to a completion rate of $20 \%$. The number of companies targeted provides an indicator of the total number of start-ups with a connection to the ten participating universities. The following universities have been participated in the Harmonized Start-up Survey: Beuth University of Applied Sciences Berlin, University of Applied Sciences Potsdam, Freie Universität Berlin, Hochschule für Schauspielkunst Ernst Busch, Hochschule für Technik und Wirtschaft Berlin, Berlin School of Economics and Law, Humboldt-Universität zu Berlin, Technische Universität Berlin, Berlin University of the Arts, and University of Potsdam. The collection and analysis of data was 
coordinated by the Centre for Entrepreneurship at Technische Universität Berlin. Out of the 750 responses, 567 were relevant for the matter of this article, whereas 333 had to be withdrawn due to the founding time of their businesses. Since the EXIST Start-up Grant was introduced in 2007, we had to remove all entrepreneurs who set up their business before that date.

\subsection{Measures}

In this article we use employee number in 2019 and sales volume in 2019 as control variables and EXIST funding as the dependent variable. This binary variable indicates a value of yes $=1$ if the entrepreneur received funding from EXIST and no $=0$ if the entrepreneur did not get funding from EXIST. For the independent variables, which were self-reported by the entrepreneurs, the authors clustered the SDGs according to their contribution to economic and social goals. The economical SDG variable includes SDG 8 (decent work and economic growth) and SDG 9 (industry, innovation, and infrastructure). The Social SDG variable sums up the following SDGs: SDG 1 (no poverty), SDG 2 (zero hunger), SDG 3 (good health and well-being), SDG 4 (quality education), SDG 5 (gender equality), SDG 10 (reduced inequalities), SDG 11 (sustainable cities and communities), SDG 12 (responsible consumption and production), SDG 16 (peace, justice and strong institutions), and SDG 17 (partnerships for the goals). As in most quantitative research, our independent variables are self-reported, which is why our dataset comes with the threat of a response bias [56,57] Respondents could overestimate their organizational capabilities to achieve certain SDG goals. Having in mind that the bias is mostly related to the query of sensitive data [58], we are confident that our results are not biased, but this bias cannot be excluded.

\subsection{Descriptive Statistics}

Descriptive statistics and correlations are presented in Table 1 and show that $43 \%$ of the respondents get EXIST support. Furthermore, the correlation matrix presents that social SDGs are negatively related to EXIST support, while economical SDGs are positively related to EXIST support. This might be a first indicator that entrepreneurs who follow economical SDG's are more likely to get EXIST funding than entrepreneurs who follow social SDGs. The correlation matrix does not show values higher than 0.513 and the variation inflation factors are below the value of 1 with a tolerance greater than 0.1 , which indicates that multicollinearity does not bias the results $[59,60]$.

Table 1. Descriptive Statistics and Correlations.

\begin{tabular}{|c|c|c|c|c|c|c|c|c|c|c|}
\hline & & Variables & Mean & SD & $\mathbf{N}$ & (1) & (2) & (3) & (4) & (5) \\
\hline Dependent variable & (1) & EXIST funding & 0.43 & 0.50 & 239 & 1 & 0.083 & -0.067 & -0.135 * & 0.143 * \\
\hline \multirow[t]{2}{*}{ Control variables } & (2) & No. of employees & 2.04 & 2.13 & 549 & 0.083 & 1 & $0.266^{* * *}$ & -0.009 & 0.030 \\
\hline & (3) & Sales volume & 3.64 & 2.25 & 543 & -0.67 & $0.266^{* * *}$ & 1 & 0.013 & 0.054 \\
\hline \multirow[t]{2}{*}{ Independent variables } & (4) & Social SDGs & 1.70 & 1.60 & 523 & $-0.135 *$ & -0.009 & 0.013 & 1 & 0.079 \\
\hline & (5) & Economical SDGs & 0.68 & 0.75 & 523 & 0.143 * & 0.030 & 0.054 & 0.079 & 1 \\
\hline
\end{tabular}

Note: ${ }^{* * *} p<0.001,{ }^{* *} p<0.01,{ }^{*} p<0.05 ;$ n.s. $p>0.05$ (two-tailed-test).

Descriptive statistics and unpaired $t$-tests (Table 2) additionally confirm that start-ups that receive EXIST funding significantly pursue more economical (Mean $=0.84, \mathrm{SD}=0.82, p<0.05$ vs. Mean $=0.61$, $\mathrm{SD}=0.72, p<0.05$ ) and less social SDGs (Mean $=1.42, \mathrm{SD}=1.37, p<0.05$ vs. Mean $=1.82, \mathrm{SD}=1.6$, $p<0.05)$ compared to their counterparts without EXIST funding. However, the number of employees and the sales volume is equally distributed between both groups and we could not find significant differences between recipients and nonrecipients. 
Table 2. Unpaired T-Test for Group Differences.

\begin{tabular}{cccccc}
\hline \multicolumn{2}{c}{ EXIST } & \multicolumn{2}{c}{ No-EXIST } \\
\hline Variables & Mean & SD & Mean & SD & Sig. (Two-Tailed) \\
\hline No. of Employees & 2.12 & 2.09 & 1.8 & 1.74 & n.s. \\
Sales Volume & 3.27 & 2.068 & 3.57 & 2.35 & n.s. \\
Social SDGs & 1.42 & 1.37 & 1.82 & 1.6 & $*$ \\
Economical SDGs & 0.84 & 0.82 & 0.61 & 0.72 & $*$ \\
\hline Note: EXIST-funding $n=102 /$ no EXIST $=137 ;{ }^{* * *} p<0.001,{ }^{* *} p<0.01,{ }^{*} p<0.05, p>0.05$ n.s.
\end{tabular}

\subsection{Logistic Regression Analysis}

Logistic regression analysis (Table 3) was used to test the research hypotheses between the likelihood of receiving EXIST funding and the pursuit of social and economic SDGs. The regression model shows good validity as the Wald test $(p<0.01)$ is significant and provides a better fit to the data than the null model [61]. Furthermore, the Hosmer \& Lemeshow test is insignificant $(p>0.05)$ indicating a reliable fit between the model and data [59]. As Hosmer-Lemeshow is a more useful evaluation indicator than the $\mathrm{R}^{2}$ indicators [61], we do not explicitly discuss the values of Cox and Snell $R^{2}$ and Nagelkerke $R^{2}$.

Table 3. Logistic Regression Analysis.

\begin{tabular}{|c|c|c|}
\hline Variables & B & $\operatorname{Exp}(ß)$ \\
\hline \multicolumn{3}{|l|}{ Controls } \\
\hline No. of employees & 0.124 & 1.132 \\
\hline Sales Volume & -0.097 & 0.147 \\
\hline \multicolumn{3}{|l|}{ Independent variables } \\
\hline Economical SDGs & $0.405^{* *}$ & 1.499 \\
\hline Social SDGs & $-0.191 *$ & 0.826 \\
\hline \multicolumn{3}{|l|}{ Model evaluation } \\
\hline Wald test & $4.905 *$ & \\
\hline \multicolumn{3}{|l|}{ Goodness-of-fit test } \\
\hline Hosmer and Lemeshow & 10.05 (n.s.) & \\
\hline Cox and Snell $\mathrm{R}^{2}$ & 0.056 & \\
\hline Nagelkerke R ${ }^{2}$ & 0.075 & \\
\hline
\end{tabular}

The regression results show that the pursuit of economic SDGs has a significant $(p<0.01)$ and positive effect on the likelihood to receive EXIST funding. Thus, entrepreneurs who follow economic SDGs are more likely to get EXIST funding which confirms our Hypothesis 1. The odds ratio $(\operatorname{Exp}(\beta=1.499)$ additionally shows that the likelihood for EXIST funding increases with increasing pursuit of economical SDGs like economic growth and innovation. Therefore, we can say that the odds of a startup pursuing economical SDGs is 1.50 times higher than those who do not follow economical SDGs. On the contrary, we could find that the pursuit of social SDGs significantly $(p<0.05)$ reduces the likelihood of receiving EXIST support, which supports our Hypothesis 2. Thus, the value of the odds ratio $(\operatorname{Exp}(B)=0.826)$ presents that the likelihood of receiving EXIST funding is 0.83 times lower when startups are aiming for social SDGs.

\section{Discussion and Conclusions}

The likelihood for getting university/university of applied sciences based EXIST funding when following economic goals can be explained in the requirements and goal of the programme that is focusing on technological innovations and requires economic feasibility. The program in general aims for all innovative and technology-based start-ups independently which SDGs are central in 
their business model. Since the change towards more and more sustainable academic start-ups in recent years, the EXIST granting program has not been adapted. The classical formulations in the description of the program might be a reason why some social entrepreneurs do not see a fit of their venture to the described requirements. Nevertheless, the programme receives applications from social entrepreneurs and there is a possibility to get the EXIST Grant as $12 \%$ of EXIST Grants are given to social entrepreneurs [19].

Although you can find special offers for female or migrant entrepreneurship, social entrepreneurship as vision-driven content, however, is lacking the attention. Therefore, it can be argued that there is still a long way to go to institutionalize social entrepreneurship and even a longer way to create comparable environmental conditions to the ones commercial entrepreneurs are enjoying. For politicians it is not easy to initiate start-up activities but initiating programs to propel social entrepreneurship would be one step [62]. Since there is interest in social entrepreneurship and the environmental conditions in Germany are not as poor, the logical step would be to promote and support social entrepreneurial activities by developing new programmes focusing on social entrepreneurs or adding to existing programmes to make them more appealing for social entrepreneurship.

Social entrepreneurs are mostly regarded as charitable organizations. However, a study from Schwab-Foundation [63] has already shown that social entrepreneurship covers the whole range from profit driven enterprises to charities. Therefore, a change in the set of applied selection criteria towards sustainability is needed. In turn, having this change would also make it much more attractive for start-ups to investigate in social and environmental problems. Moreover, changing the judgement of start-ups away from purely profit-driven to impact driven (social, ecological, and economical) would probably create a much stronger foundation of the economic and societal changes ahead.

From a global perspective, the developed countries such as Germany are supposed to go ahead when it comes to the promised global changes. The SGDs witness the global intentions. However, the developed countries still stick to the old paradigm of economic growth and profit manifesting the overuse of many resources. Furthermore, in these points Germany could invest more in the development, missions, and visions of future enterprises by fostering social impact the same way as economic success.

The purpose of this article was to unfold differences in access to funding for commercial and social entrepreneurs in Germany. We collected data on entrepreneurs who were supported in the process of EXIST Start-up Grant application. Our research results revealed a difference in likelihood of getting the EXIST funding in terms of economic and social SDGs. Concerning contributions to practice, we suggest policymakers should draw more attention to social entrepreneurs by creating new programmes or redefining the criteria of existing programmes. Improving the conditions and creating incentives for social entrepreneurs could help social entrepreneurs fighting social challenges and contribute to sustainable development.

Key limitations include the fact that the data is self-reported, meaning that there is a tendency for biased results since entrepreneurs might overestimate their competence in targeting the SDGs. The application of the SDGs in self-reports is difficult due to the very general definition of the SDGs themselves, which leave space for different interpretations. Future research should maybe reformulate the SDGs into use-cases. In addition, the separation into economical, ecological, and social aiming SDGs can only be made with experts who sort them. However, the SDGs themselves slightly overlap in this categorization. Furthermore, the study was drawn from a broad sample in Berlin and Brandenburg and we cannot statistically account for a nested structure [59]. Thus, it might be that entrepreneurs belonging to the same incubator, university, or city are more homogeneous related to entrepreneurs belonging to other clusters. Moreover, due to limiting data on other programmes, the analysis could only include the EXIST Start-up Grant.

Despite the limitations, this article adds a new perspective on formal institutions by analyzing two different forms of entrepreneurship within one national context. Further research can complement and verify the results by replicating the study in other contexts and countries to avoid generalization of 
(nation-specific) results [64]. Furthermore, adding further control variables on the organizational level like other funding sources, level of equity, legal status, as well as normative and cognitive dimensions at the individual level of the founder help in understanding the complex environment that influences social entrepreneurship $[65,66]$. As mentioned above, the Micro-Mezzanine Fund is the only program that addresses also social entrepreneurs. Therefore, the Micro-Mezzanine Fund can be analyzed on its difference in terms of its availability for commercial and social entrepreneurs. For a more general picture, all governmental programmes should be analyzed in terms of their allocation to specific entrepreneurial forms. Moreover, qualitative follow-up studies could be conducted to clarify the findings. Finally, we propose to apply the NECI to social entrepreneurship in order to analyze the environmental framework conditions for social entrepreneurs on the country level. This might help to reveal the difference between commercial and social entrepreneurship, inform political decisions, and boost social entrepreneurship with its contribution to have a higher chance of reaching the SDGs. Finally, a more integrated and multidisciplinary approach could provide a higher level of insights into the relationship of governmental support and social entrepreneurship.

Author Contributions: Conceptualization, K.C. and J.K.; Data curation, K.F. and M.J.G.; Formal analysis, K.C., J.K. and L.H.v.A.; Investigation, K.F. and M.J.G.; Methodology, J.K. and L.H.v.A.; Project administration, K.C.; Supervision, J.K.; Writing-original draft, K.C. and L.H.v.A.; Writing-review \& editing, K.C., J.K., L.H.v.A., K.F. and M.J.G. All authors have read and agreed to the published version of the manuscript.

Funding: We acknowledge support by the German Research Foundation and the Open Access Publication Fund of TU Berlin.

Acknowledgments: The authors want to thank all universities and universities of applied sciences from Berlin and Brandenburg who participated in this survey.

Conflicts of Interest: The authors declare no conflict of interest.

\section{References}

1. Korosec, M.L.; Berman, E.M. Municipal support for social entrepreneurship. Public Adm. Rev. 2006, 66, 448-462. [CrossRef]

2. Massetti, B.L. The Social Entrepreneurship Matrix as Tipping Point for Economic Change. Emerg. Complex. Organ. 2008, 10, 1-8.

3. Mort, G.S.; Weerawardena, J.; Carnegie, K. Social entrepreneurship: Towards conceptualisation. Int. J. Public Sect. Manag. 2003, 8, 76-88.

4. Mair, J.; Martí, I. Social entrepreneurship research: A source of explanation, prediction, and delight. J. Bus. World 2006, 41, 36-44. [CrossRef]

5. Thompson, J.; Doherty, B. The diverse world of social enterprise. Int. J. Soc. Econ. 2006, 5, 361-375. [CrossRef]

6. Apostolopoulos, N.; Al-Dajani, H.; Holt, D.; Jones, P.; Newbery, R. Entrepreneurship and the Sustainable Development Goals. In Entrepreneurship and the Sustainable Development Goals (Contemporary Issues in Entrepreneurship Research, Volume 8); Emerald Publishing Limited: Bingley, UK, 2018; pp. 1-7.

7. Barberá-Tomás, D.; Castelló, I.; de Bakker, F.G.A.; Zietsma, C. Energizing through Visuals: How Social Entrepreneurs Use Emotion-Symbolic Work for Social Change. Acad. Manag. J. 2019, 62, 1789-1817.

8. Horne, J.; Recker, M.; Michelfelder, I.; Jay, J.; Kratzer, J. Exploring entrepreneurship related to the sustainable development goals-mapping new venture activities with semi-automated content analysis. J. Clean. Prod. 2020, 242, 118052. [CrossRef]

9. Smith, W.K.; Gonin, M.; Besharov, M.L. Managing social-business tensions: A review and research agenda for social enterprise. Bus. Ethics Q. 2013, 23, 407-442. [CrossRef]

10. Scharpe, K.; Wunsch, M. Deutscher Social Entrepreneurship Monitor 2019; Social Entrepreneurship Netzwerk Deutschland e.V: Berlin, Germany, 2019; Available online: https://www.send-ev.de (accessed on 11 September 2020).

11. Sassmannshausen, S.P.; Volkmann, C. The Scientometrics of Social Entrepreneurship and Its Establishment as an Academic Field. J. Small Bus. Manag. 2018, 56, 251-273. [CrossRef]

12. Gupta, P.; Chauhanb, S.; Paulc, J.; Jaiswald, M.P. Social entrepreneurship research: A review and future research agenda. J. Bus. Res. 2020, in press. [CrossRef] 
13. Verheul, I.; Wennekers, S.; Audretsch, D.; Thurik, R. An Eclectic Theory of Entrepreneurship: Policies, Institutions and Culture. In Entrepreneurship: Determinants and Policy in a European-US Comparison. Economics of Science, Technology and Innovation; Audretsch, D., Thurik, R., Verheul, I., Wennekers, S., Eds.; Springer: Boston, MA, USA, 2002; Volume 27.

14. Singh, J.; Tucker, D.; House, R. Institutional Factors in Organizational Foundings. 1989; Unpublished paper.

15. Bruton, G.D.; Ahlstrom, D.; Li, H.L. Institutional Theory and Entrepreneurship: Where Are We Now and Where Do We Need to Move in the Future? Entrep. Theory Pract. 2010, 34, 421-440. [CrossRef]

16. Evans, P. Government action, social capital and development: Reviewing the evidence on synergy. World Dev. 1996, 24, 1119-1132. [CrossRef]

17. Zahra, S.A.; Wright, M. Entrepreneurship's next act. Acad. Manag. Perspect. 2011, 25, 67-83. [CrossRef]

18. Social Entrepreneurs als Akteure der ökologischen und sozialen Modernisierung der Wirtschaft stärken. Available online: http://dip21.bundestag.de/dip21/btd/19/072/1907293.pdf (accessed on 11 September 2020).

19. Bundesregierung. Antwort der Bundesregierung auf die Kleine Anfrage der Abgeordneten Dieter Janecek, Markus Kurth, Dr. Danyal Bayaz, weiterer Abgeordneter und der Fraktion BÜNDNIS 90/DIE GRÜNEN-Drucksache 19/6844-Social Entrepreneurs als Akteure der ökologischen und sozialen Modernisierung der Wirtschaft stärken. Casper, S. 2000. Institutional Adaptiveness, Technology Policy, and the Diffusion of New Business Models: The Case of German Biotechnology. Organ. Studies 2019, 21, 887-914.

20. Agapitova, N.; Sanchez, B.; Tinsley, E. Government Support to the Social Enterprise Sector: Comparative Review of Policy Frameworks and Tools; The World Bank Washington: Washington, DC, USA, 2017.

21. Middermann, L.H.; Rashid, L. Cross-Country Differences in Entrepreneurial Internationalization Tendencies: Evidence from Germany and Pakistan. Adm. Sci. 2019, 9, 54. [CrossRef]

22. Pinho, J.C. Institutional theory and global entrepreneurship: Exploring differences between factor-versus innovation-driven countries. J. Int. Entrep. 2017, 15, 56-84. [CrossRef]

23. Van Praag, C.M.; Versloot, P.H. What is the value of entrepreneurship? A review of recent research. Small Bus Econ. 2007, 29, 351-382. [CrossRef]

24. Bergmann, S. The Changing Face of Entrepreneurship in Germany. Small Bus. Econ. 2007, 28, $205-221$. [CrossRef]

25. Bittorf, M. Die Kultur der Selbstständigkeit in Deutschland-Defizite und Potenziale. KFW ECONOMIC RESEARCH, Fokus Volkswirtschaft Nr. 39, 18, Dezember 2013. Available online: https: //www.kfw.de/PDF/DownloadCenter/Konzernthemen/Research/PDF-Dokumente-Fokus-Volkswirtschaft/ Fokus-Nr.-39-Dezember2013.pdf (accessed on 11 September 2020).

26. Herzog, R. Aufbruch ins 21. Jahrhundert. 1997. Available online: http://www.bundespraesident.de/ SharedDocs/Reden/DE/RomanHerzog/Reden/1997/04/19970426_Rede.html (accessed on 11 September 2020).

27. GEM Global Entrepreneurship Monitor, January 2020. Available online: http://www.gemconsortium.org/data (accessed on 11 September 2020).

28. Metzger, G. KfW-Gründungsmonitor 2020. KfW Bankgruppe, Abteilung Volkswirtschaft. 2020. Available online: https://www.kfw.de/KfW-Konzern/KfW-Research/KfW-Gr\%C3\%BCndungsmonitor.html (accessed on 11 September 2020).

29. Bosma, N.; Kelley, D. Global Entrepreneurship Monitor: 2018/2019. Available online: https://www. gemconsortium.org/file/open?fileId=50213 (accessed on 28 October 2020).

30. Bosma, N.; Hill, S.; Ionescu-Somers, A.; Kelley, D.; Levie, J.; Tarnawa, A. Global Entrepreneurship Monitor 2019/2020 Global Report. Available online: https://www.gemconsortium.org/file/open?fileId=50443 (accessed on 28 October 2020).

31. Sternberg, R.; Gorynia-Pfeffer, N.; Wallisch, M.; Baharian, A.; Stolz, L.; von Bloh, J. Global Entrepreneurship Monitor Unternehmensgründungen im Weltweiten Vergleich Länderbericht Deutschland 2019/2020. 2020. Available online: https:/www.rkw-kompetenzzentrum.de/gruendung/studie/global-entrepreneurshipmonitor-20192020/ (accessed on 11 September 2020).

32. Cagarman, K.; Kratzer, J.; Osbelt, K. Social Entrepreneurship: Dissection of a Phenomenon through a German Lens. Sustainability 2020, 12, 7764. [CrossRef]

33. Dees, G. The Meaning of Social Entrepreneurship. 1998. Available online: https://centers.fuqua.duke.edu/ case/knowledge_items/the-meaning-of-social-entrepreneurship/ (accessed on 11 September 2020).

34. Defourny, J.; Nyssens, M. Conceptions of Social Enterprise and Social Entrepreneurship in Europe and the United States: Convergences and Divergences. J. Soc. Entrep. 2010, 1, 1-26. [CrossRef] 
35. Defourny, J. From third sector to social enterprise. In The Emergence of Social Enterprise; Borzaga, C., Defourny, J., Eds.; Routledge: London, UK; New York, NY, USA, 2001; pp. 1-28.

36. Esping-Andersen, G. The Three Worlds of Welfare Capitalism; Princeton University Press: Princeton, NJ, USA, 1990.

37. Salamon, L.M.; Sokolowski, S.W. Global Civil Society Dimensions of the Nonprofit Sector, Bloomfield; Kumarian Press: West Hartford, CT, USA, 2004; Volume 2.

38. Schwarz, S. Social Entrepreneurship Projekte; Springer Fachmedien Wiesbaden: Wiesbaden, Germany, 2014.

39. World Bank. Doing Business 2020. Starting a Business Ranking. World Bank: Washington, DC, USA. Available online: https://www.doingbusiness.org/en/rankings (accessed on 11 September 2020).

40. Leppert, T. Social Entrepreneurs in Deutschland-Ansätze Und Besonderheiten Einer Spezifischen Definition; Social Startup-Beratung für Soziale Bewegungen/Universität Hamburg: Hamburg, Germany, 2008; pp. 1-14.

41. Commission Expert Group on Social Entrepreneurship (GECES). Social Enterprises and the Social Economy Going Forward. Available online: https:/ec.europa.eu/growth/content/social-enterprises-and-socialeconomy-going-forward_en (accessed on 11 September 2020).

42. Kollmann, T.; Hensellek, S.; Benedikt, J.; Kleine-Stegemann, L. Deutscher Startup Monitor 2019. Available online: https://deutscherstartupmonitor.de/fileadmin/dsm/dsm-19/files/Deutscher_Start-Monitor_2019.pdf (accessed on 11 September 2020).

43. Thomson Reuters Foundation. The Best Countries to be a Social Entrepreneur 2019. Available online: http://poll2019.trust.org/country/?id=germany (accessed on 11 September 2020).

44. Baumol, W.J.; Litan, R.E.; Schramm, C.J. Good Capitalism, Bad Capitalism, and the Economics of Growth and Prosperity; Yale University Press: New Haven, CT, USA, 2009.

45. Veciana, J.M. Entrepreneurship as a scientific research programme. In Entrepreneurship: Concepts, Theory and Perspective; Cuervo, A., Ribeiro, D., Roig, S., Eds.; Springer: Heidelberg, Germnay, 2007; pp. 23-71.

46. North, D.C. Institutions, Institutional Change and Eco-Nomic Performance; Cambridge University Press: Cambridge, UK, 1990.

47. Scott, W.R. Institutions and Organizations: Ideas and Interests; Sage Publications: Thousand Oaks, CA, USA, 2007.

48. DiMaggio, P.J.; Powell, W.W. Introduction. In The New Institutionalism in Organizational Analysis; Powell, W.W., DiMaggio, P.J., Eds.; University of Chicago Press: Chicago, IL, USA, 1991; pp. 1-38.

49. Kostova, T. Country Institutional Profiles: Concept and Measurement. Best Pap. Proc. Acad. Manag. 1997, 1997, 180-184. [CrossRef]

50. Suchman, M.C. Managing legitimacy: Strategic and institutional approaches. Acad. Manag. Rev. 1995, 20, 571-610. [CrossRef]

51. Aldrich, H.E. Using an ecological perspective to study organizational founding rates. Entrep. Theory Pract. 1990, 14, 7-24. [CrossRef]

52. Ahlstrom, D.; Bruton, G.D. Learning from successful local private firms in China: Establishing legitimacy. Acad. Manag. Exec. 2001, 15, 72-83. [CrossRef]

53. BMWi. Financing Start-Ups and Growth: Overview of Funding Instruments. 2019. Available online: https://www.bmwi.de/Redaktion/EN/Downloads/financing-start-ups-and-growth-overview-offunding-instruments.pdf?_blob=publicationFile\&v=9 (accessed on 11 September 2020).

54. BMWi. Das ist EXIST 2019. 2020. Available online: https://www.bmwi.de/Redaktion/DE/Publikationen/ EXIST/exist-das-ist-exist-2019.pdf?_blob=publicationFile\&v=14 (accessed on 11 September 2020).

55. Stephan, U.; Uhlaner, L.M.; Stride, C. Institutions and social entrepreneurship: The role of institutional voids, institutional support, and institutional configurations. J. Int. Bus. Studies 2015, 46, 308-331. [CrossRef]

56. Kautonen, T.; van Gelderen, M.; Fink, M. Robustness of the Theory of Planned Behavior in Predicting Entrepreneurial Intentions and Actions. Entrep. Theory Pract. 2015, 39, 655-674. [CrossRef]

57. Von Arnim, L.; Mrozewski, M. Entrepreneurship in an Increasingly Digital and Global World. Evaluating the Role of Digital Capabilities on International Entrepreneurial Intention. Sustainability 2020, 12, 7984. [CrossRef]

58. Carr, J.C.; Sequeira, J.M. Prior family business exposure as intergenerational influence and entrepreneurial intent: A Theory of Planned Behavior approach. J. Bus. Res. 2007, 60, 1090-1098. [CrossRef]

59. Field, A. Discovering Statistics Using SPSS, 3rd ed.; Sage Publications: New York, NY, USA, 2009. 
60. Midi, H.; Sarkar, S.K.; Rana, S. Collinearity diagnostics of binary logistic regression model. J. Interdiscip. Math. 2010, 13, 253-267. [CrossRef]

61. Peng, C.-Y.J.; Lee, K.L.; Ingersoll, G.M. An Introduction to Logistic Regression Analysis and Reporting. J. Educ. Res. 2002, 96, 3-14. [CrossRef]

62. Wagner, J.; Sternberg, R. Start-Up Activities, Individual Characteristics, and the Regional Milieu: Lessons for Entrepreneurship Support Policies from German Micro Data. Ann. Reg. Sci. 2004, 38, 219-240. [CrossRef]

63. Weber, C.; Kratzer, J. Social entrepreneurship, social networks and social value creation: A quantitative analysis among social entrepreneurs. Int. J. Entrep. Ventur. 2013, 5, 217-239. [CrossRef]

64. Terjesen, S.; Hessels, J.; Li, D. Comparative International Entrepreneurship. J. Manag. 2016, 42, $299-344$. [CrossRef]

65. Meek, W.R.; Pacheco, D.F.; York, J.G. The impact of social norms on entrepreneurial action: Evidence from the environmental entrepreneurship context. J. Bus. Ventur. 2010, 25, 493-509. [CrossRef]

66. Middermann, L.H.; Kratzer, J.; Perner, S. The Impact of Environmental Risk Exposure on the Determinants of Sustainable Entrepreneurship. Sustainability 2020, 12, 1534. [CrossRef]

Publisher's Note: MDPI stays neutral with regard to jurisdictional claims in published maps and institutional affiliations.

(C) 2020 by the authors. Licensee MDPI, Basel, Switzerland. This article is an open access article distributed under the terms and conditions of the Creative Commons Attribution (CC BY) license (http://creativecommons.org/licenses/by/4.0/). 